\title{
A TÖRTÉNETI GENETIKA TÖRTÉNETI RELEVANCIÁJÁRÓL
}

\section{ON HISTORICAL RELEVANCE OF ARCHAEOGENETICS}

\author{
Bálint Csanád \\ az MTA rendes tagja, kutatóprofesszor, MTA Bölcsészettudományi Kutatóközpont Régészeti Intézet \\ balint.csanad@btk.mta.hu
}

\begin{abstract}
ÖSSZEFOGLALÁS
E cikk a tényleges együttműködés szükségességét hangsúlyozza a történeti genetika, a történettudomány, a régészet és a nyelvtudomány múvelői között. Módszertani okokon túl részben azért is van rá szükség, mert a helyi lakosság továbbélése miatt a kora középkori temetők nem közvetlen tükröződései a régi népességeknek, részben pedig mert a temetők szociális egységek és nem etnikai csoportok nyugvóhelyei voltak. Jelenleg a módszertanilag leginkább megalapozott folyamatban levő és Patrick Geary vezette kutatás a langobárd vándorlásokat vizsgálja, ami tanulságot kínál a magyar őstörténet hasonló megközelítései számára is. A szerző a történeti genetika hatalmas történeti relevanciáját az egyes temetők rokonsági viszonyainak, a népvándorlásoknak a stronciumizotópos adatokkal kombinált vizsgálatában és az eredetkérdéseket új szempontból megvilágítva az állati és növényi maradványok elemzésében látja.
\end{abstract}

\begin{abstract}
The present paper argues for the need of deepening meaningful collaboration between the specialist of archaeogenetics, history, archaeology, and linguistics because the results of scientific analyses can hardly be accurately interpreted without a familiarity with the appropriate methodology and current approaches of the humanities. It is particularly important to understand that cemeteries are not direct reflections of past populations, given that European populations were highly heterogeneous since the Bronze Age: incoming groups were similarly mixed, while local populations survived, especially in the Carpathian Basin. Moreover, cemeteries are social constructs, while genetics study individuals. The most promising and methodologically most sound example of interdisciplinary research in this field known to the present author is the ongoing project launched and directed by Patrick Geary focusing on the Lombard migrations. The theoretical framework created for, and the preliminary results of, this project offer a strong caveat for researchers of the prehistory of the Hungarian people too, given that both the geographical and chronological frameworks of the migration of the ancient Hungarians are far less securely known than in the case of the Lombards. In view of these problematic points, the author of the present study argues that the most valuable contribution of archaeogenetics to historical studies is the analysis of kinship relations in cemeteries as well as of zoological and botanical remains.
\end{abstract}


Kulcsszavak: történeti genetika, interdiszciplinaritás, történeti relevanciák

Keywords: archaeogenetics, interdisciplinarity, historical relevances

Panta rhei

(Hérakleitosz)

A történeti genetikában sokfelé számtalan megfigyelés születik számtalan részkérdésben, mindenki adatbázist épít, állandóan új eljárások és müszerek jelennek meg, megszületett a genomika, korábban elképzelhetetlenül gyors számítógépes programok készülnek, miközben e diszciplína történeti vagy genetikai képzettség nélküli amatőröknek is kedvenc hétvégi kirándulóhelye lett. A kutatás változatlanul a heurisztikus korát éli, mindenkit eltölt az egyes mérések fölötti öröm. Mégis: quo vadis archaeogenetica? Nem újabb, Luigi L. Cavalli-Sforza-típusú összefoglalásokat hiányolok, de például történeti szempontból a haplotípusok és altípusaik tértől és időtől független számbavétele a cikkekben történetileg irreleváns. A haplotípusok regionális előfordulásainak fölsorolásakor azok szinkron és diakron bemutatása lenne történetileg informatív: úgy összehasonlítani az egyes régiók hasonlóságait és eltéréseit, hogy változott-e a genetikai összetételük az idők folyamán, s ha igen, hol és mikor, miközben másutt nem? Márpedig amíg egyazon régióból nem, vagy csak elszórtan áll rendelkezésre adatsor a kronológiailag egymást követő periódusokból, addig nem dönthető el, hogy egy bizonyos haplotípus előfordulása egy új népcsoport fölbukkanását jelzi-e, vagy az az adott mikrorégióban már korábban is jelen volt - máskülönben az előfordulások történeti interpretációi esetlegesek.

A kívülálló örülne, ha szó esnék a kutatások során nyert adatok időtálló voltáról és abszolút értékéről is. Ezerszámra születnek az újabbak, úgyhogy jó volna tudni azt is, amit a közismert vicc fejez ki: „,mi mennyi?” (Értsd: mi az az „adat”?) Ehhez multidiszciplináris együttmüködésre van szükség: a genetikai minták kiválasztásához régész ${ }^{1}$, a genetikusok által nyert adatok feldolgozásához informatikus, történeti értékeléséhez történész tájékozottság kell; egy-egy angol nyelvü kézikönyv, lexikoncikk használata önmagában nem elegendő, ha nem ép-

\footnotetext{
${ }^{1}$ A régésszel való szoros együttmüködés elengedhetetlen voltát lehangolóan illusztrálta az az eset, amikor az egyik vezető genetikai folyóiratban négy magyarországi neolit kori minta eredményeit adták közzé. Minthogy a Kárpát-medence Európa neolit kori benépesülésének egyik fő kiindulópontja, e közlemény - az akkor rendelkezésre álló adatok minimális száma miatt - nagy horderejünek tủnt. Aztán kiderült, hogy három minta szarmata, a negyedik honfoglalás kori sírból származik. És e közlemény peer review-k után, egy magas citációs indexủ folyóiratban jelent meg: Guba et al., 2011. Kritikája: Bánffy et al., 2012.
} 
pen félrevezető lehet. ${ }^{2}$ (A szóládi langobárd temető földolgozása mutatja a jövőben követendő megközelítésmódot és a stronciumizotópos vizsgálat fontosságát [Alt, 2014].) A mérlegelések mellé egy nem kis horderejü tudományelméleti kérdés is kerül. Terjed az a gyakorlat, amely az elavultnak minősülö metodikákkal nyert adatokat nem használja többé, az olyanokkal végzett újabb eredményeket a szerkesztőségek nem fogadják el közlésre. Tény, hogy a genomika megjelenése és a nagy áteresztőképességgel rendelkező technológiák generációs váltásai következtében folyamatosan árnyaltabb adatok születnek - ez a kutatás természetes velejárója. Ámde mert a Juno szonda összehasonlíthatatlanul jobban „látja” a Jupitert, még nem feledkezünk meg Keplerröl. A müszerek versenyfutásában a korábban nyert adatok elvetése a tudomány fejlődésének tagadását jelentené, lemondást az adatok akkumulálódása révén nyerhető haladásról. Ha viszont a mai adat holnapra elévülhet, akkor a mai eredményeket is e szemlélet fényében kell kezelni! Mi bölcsészek sokszor megkapjuk: no discussion, only facts! Csakhogy mi a ,fact”, ha annak értéke változhat? (Lásd Pléh Csaba cikkét e szám 148-152. oldalain.) Nem bölcsész jellegzetesség, a történeti genetikában is előfordul, hogy azonos müszerekkel, azonos tudományos kultúrájú közegben folytatott mérések értékelése homlokegyenest eltérő lehet (lásd Jörg Feuchter és Koncz István cikkét e szám 126-132. és 133-139. oldalain). Az adatok abszolút (?) értékének megítélését (és az abból is táplálkozó tudománypolitikai felfogást) érdemes újragondolni.

A történeti genetikától közvetlen rokonságok, valamint vándorlások, etnikai vonások kimutatását szokták várni (a diszciplína bemutatása: Kurt W. Alt cikke e szám 101-114. oldalain). A legelső esetében valóban döntő tud lenni, mert a kérdés konkrét: rokon-e vagy sem? A második már jóval problematikusabb: maga a „népvándorlás” is vitatott fogalom (lásd alább és Jörg Feuchter cikke e szám 126-132. oldalain); genetikai kimutatásához térben, időben és nagy mintaszámmal végzett nemzetközi vizsgálatokra volna szükség, amelyek elvégzésére egyegy kutatócsoport nem képes (lásd alább). Nagyon nagy viszont a genetika súlya egy állat- vagy növényfaj vizsgálata során, ezt az etruszk eredetkérdés (helyi és/ vagy kis-ázsiai?) esete jól példázza: az emberi és a szarvasmarhacsontok ugyanis mást-mást mutatnak! (URL1) Ugyanilyen nagy horderejü történeti következtetés lehetőségét rejti, hogy az avar kori lovak genetikai variabilitása magas, a honfoglalás koriak genetikai diverzitása éppenséggel kiemelkedően magas, és a vizsgáltak között csak egy esetben egyezett meg a szekvenciamintázat (Priskin, 2010,

${ }^{2}$ Erre a helyzetre célzott egy vitacikk címe: Simon, 2005. A Vergiliustól vett idézet (Aeneis 2.310) arra figyelmeztetett, hogy már a tudományos világon belül - ebben az esetben: a történeti genetikában - is megjelent a veszély: az adott diszciplínától távol álló alkot véleményt tudományos kérdésben. Hogy éppen egy tudós miért gondolhatja, hogy érdemben hozzászólhat egy, az övétől alapvetően eltérő képzettséget és olvasottságot igénylő tudományág problémáihoz, annak pszichológiai, társadalom-lélektani vonatkozásával külön kell(ene) foglalkozni. 
48-49.). Etnikumra következtetni viszont - különleges történeti helyzetektől eltekintve (például Izland benépesülése) - igen bizonytalan. Az 'etnikum' fogalma ui. mindennél összetettebb: semmiképpen sem biológiai, hanem elsősorban történeti, kulturális és szociális megnyilvánulás. Már a vele foglalkozó hatalmas történeti és régészeti irodalom (például: Gillett, 2002; Brather, 2004) áttanulmányozása nélkül is könnyű belátni: egy temetőt használó közösség tagjainak etnikai hovatartozása nem állapítható meg (lásd Jörg Feuchter cikke). A régészetileg és genetikailag különösen intenzíven kutatott Közel-Kelet fontos figyelmeztetést ad: míg a régészeti kultúrája egységes, genetikailag heterogén volt, már a Krisztus előtti évezredekben is! (Lásd Alt cikke.)

Keresik a történeti genetika lehetséges relevanciáját a nyelvekkel összefüggésben is. Ez sokszor nemcsak a nyelvtudomány elméleti részében, hanem a nyelvek történetében és viszonyrendszerében, egy sor nyelvészeti alaptételben is tájékozatlanságot mutatva történik (lásd Bakró-Nagy Marianne cikkét e szám 140-147. oldalán). Vannak viszont kecsegtető perspektívák, így a nyelvi kontaktusok genetikai tükröződéseinek kutatása, például bizonyos haplotípusok és bizonyos nyelvi jelenségek között összefüggésekre bukkantak. ${ }^{3}$ Amennyiben valóban egybeesés van egy bizonyos marker különböző népcsoportokban való jelenléte és ugyanazon népek nyelvtörténeti kronológiája között, az lehet előrevivő eredmény. Nemrég a történeti genetikai kutatás egész irányultságában minőségi változás következett be: a Max-Planck-Gesellschaft 2014-ben az Institut für Menschheitsgeschichte megalapításával intézményes lépést tett a genetika és a történet- és nyelvtudomány összehangolására. (Mindkét - a megszüntetett és az életre hívott új - tudományterület számára igen tanulságos, hogy ezt egy húsz évvel korábban gazdasági rendszerek kutatására alapított intézet helyébe létesítették!) A jénai intézetnek két igazgatója van, ami a két diszciplína egyenrangú kezelésmódjáról tanúskodik: az egyikük genetikus, a másik nyelvész. Még ha mindkettejük munkásságát vitatják is, ez is lehet egy út, amelyik elvezethet egy valóban történeti genetika megszületéséhez. ${ }^{4}$ Ugyanígy tanulságot sugall történészek és genetikusok számára az etológus Miklósi Ádám cikke (e szám 153-163. oldalán).

A történeti genetika egy-egy eredménye a tömegtájékoztatásban rendszeresen hírré válik (cro-magnoni és Neander-völgyi ember keveredése, Amerika indián betelepedése, baszk eredetkérdés stb.). Eurázsia benépesülésének történetét, Európa mai genetikai képének kialakulását valóban meggyőzően sikerült föltárni (lásd Alt cikke). A történeti korokról már ritkábban esik szó, mert genetikailag kevésbé kutatottak, és kevésbé várható tőlük sajtószenzáció (és támogatás elnyerése), de

\footnotetext{
${ }^{3}$ Magyar nyelvü, az Y-kromoszóma vizsgálatokra nézve tanulságos áttekintésük: Pamjav et al., 2016.

${ }^{4}$ A népek keveredésével, a népvándorlások genetikai kutatásával kapcsolatos korábbi megjegyzéseim: Bálint, 2008.
} 
etnikailag fölhasználható eredmény sem (politikailag sajnos inkább). A Krisztus utáni évszázadoktól kezdve ui. kontinensünk etnikai képe rendkívül bonyolult lett. Már a Római Birodalomban is követhetetlen volt a keveredés: germán csoportok, zsidók, szírek és afrikaiak kerültek be, ugyanakkor különféle „rómaiak” érkeztek - többek között - 'Germania'-ba, de 'Pannonia'-ba is. A 'Britannia'-tól 'Palestina'-ig terjedő, Észak-Afrikát is magába foglaló birodalomban a különböző tartományokból toborzott légióknak máshová vezérlése, a betelepülések, betelepítések és beszivárgások révén a Mediterráneum etnikai összetétele már a népvándorláskor előtt is igen tarka volt. Ezt Európában a nagy kiterjedésü középkori, újkori és legújabb kori népmozgások és telepítések végtelenül bonyolulttá tették - a történeti genetikai kutatás lassan rájött, hogy modern mintáktól semmiképpen sem várható válasz etnogenetikai kérdésekre. Az avarok és honfoglaló magyarok eredete kutatásakor tehát e szemmel kell nézni Ázsiára, ahonnan még Európánál is kevesebb történeti forrás áll rendelkezésre. ${ }^{5}$

Az egyes ,népek” mindig keveredettek. Mindig számolni kell a helyi lakosság továbbélésével: sosincs tabula rasa; Európa mai genetikai alapképe már a bronzkorban kialakult, s azon kevés változás esett (lásd Alt cikke). A Kárpát-medencében a paleolitikum óta sok és sokféle nép telepedett le (egyedül észak felöl nem). Egy nép sem tủnik el nyomtalanul: az egyes régészeti, történeti korszakok beköszöntekor az adott régió sosem lakatlan, s az ott élők (esetleg csak a maradványaik) mindig beolvadtak, azaz továbbadták a génjeiket. Költői túlzással: minden korábban itt élt nép vére csörgedezik bennünk! (Éppenséggel - nagy ritkán - ma is látni közöttünk a Neander-völgyi emberhez antropológiailag hasonlítót, míg cro-magnoni típusúból többet is!) „Népvándorlásként” - azaz nem lassú elvándorlásként (mint például a neolitikumban) csak a kelták és a langobárdok költöztek innen tovább. A régész a leletanyagot történetileg periodizálja: „szarmatakor”, „,hunkor”, „germán népek kora”, ,,avarkor” stb., de genetikai szempontból legkevésbé sem gondolható, hogy például a hunkorban ne éltek volna még az azt megelőzően az Alföldön négyszáz éven át lakó szarmaták is. A honfoglaló magyarok 10. századi temetőit genetikailag vizsgálva megtalálhatjuk bennük az avarok leszármazottait (akik eredetileg maguk is sokféle keleti és germán, szláv elem keveredéséből valók voltak), a szlávok mindhárom csoportjába tartozókat (keleti, nyugati és déli szlávok), bajor telepeseket, és akadhattak még a kalandozások során behurcolt rabszolgák is. Kevés régió van Európában (az északkeleti sarkán kívül), amelyet viszonylag kevéssé érintettek bevándorlások; ha fontosnak tartanák, Nagy-Britannia lakói éppenséggel „hármas honfoglalással” dicsekedhetnének (kelta, angolszász, normann). „Népeket” genetikailag azonosítani

\footnotetext{
${ }^{5}$ Például a belsö-ázsiai történelem egyik legfontosabb, 8. századi forrása egy tucatnyi népnevet sorol fel - jó néhányukról a nevükön kívül semmi többet nem tudunk (lásd Berta, 2004, 25-87.), amint az Ószövetségben említett számtalan népről sem.
} 
illúzió (lásd Alt és Feuchter cikke), de óriási jelentőségủ a genetika, amikor meg tudja világítani bevándorlók és helyiek számarányát. Egy nép fennmaradásának sikere nem feltétlenül a számbeli fölényétől függ (lásd Feuchter és Koncz cikke); ez a nyelv esetében már régóta köztudott (legutóbb: Grenoble, 2011).

Nincsen „tiszta” nép. A nálunk sokak fantáziáját megmozgató hunok eredete és nyelve ismeretlen, talán az is marad (török vagy mongol vagy ismeretlen paleoszibériai). Tetézi ezt, hogy a Kárpát-medencébe érkezettek további, számunkra ismeretlen összetételü, egyáltalán nem kizárólag a török vagy mongol népek családjába tartozó csoportokat is sodorhattak magukkal, mind Ázsiából, mind a kelet-európai sztyeppéről. Másik példa: az Attila birodalmában élt gótok ősei Krisztus születése táján a Visztula torkolatvidékéről költöztek Mazurián keresztül a délorosz sztyeppére és a Krímbe, aztán a Dunántúlra, ahonnan más-más csoportjaik a Balkánra és Itáliába mentek, megint más „gótok” az Ibériai félszigeten létesítettek kétszáz éven át fennálló királyságot - ők vajon genetikailag miként volnának megragadhatók?

Kik a jövevények? A honfoglalásokat, népvándorlásokat illetően a történettudomány jó ideje elszakadt attól a 19. században Európa-szerte elterjedt romantikus képtől, amit nálunk a Feszty-körkép is sugall. ${ }^{6}$ Olyan felfogás is van, amelyik kétségbe vonja a népvándorlások létét, $\mathrm{s}$ helyette katonai egységek mozgásáról beszél. Ilyen volt immár száz éve a hunok esetére vonatkoztatva Alföldi András „kozák teóriája” (mai terminussal: kommandós csapat, nők nélkül), azaz hogy a „hunok" valójában csak katonai erőként jelentek meg a Kárpát-medencében, s nem népességként. Ilyenre következtethetünk azon 670/680 körüli onogur-bolgár bevándorlással kapcsolatban is, melynek leírásában a bizánci forrás a vezérük „hadseregéröl” ír, míg minden más eseménynél „nép”-ről. Ezért lesznek hát perdöntőek az elterjedőben levő Y-kromoszóma vizsgálatok: megvilágíthatják, hogy egy-egy régióban mennyire népcsoportok bukkantak fel, vagy inkább csak férfiak, akik aztán összeházasodtak a helybeli nőkkel. (Érdekesség: a középkori Közép- és Dél-Európában éppenséggel a nők voltak mobilisak [lásd Kowaleski, 2013].) Nem csak egy különös terminus volt a peloponnészoszi félsziget 5-6. századi elszlávosodásának folyamatát „lopakodó honfoglalásnak” nevezni, ti. az tényleg nem egy katonai esemény eredménye volt. A hazai kutatás egyik részében is terjedőben van a 9. század végi magyarokkal kapcsolatban az a szemléletmód, amelyik nem egyetlen, dicsőséges haditettel, hanem szakaszokban lezajlott betelepüléssel számol.

Mi a temetö? A régész előtt nem pusztán a halott csontjai és tárgyai állnak, hanem egy sokféle szempont alapján szerveződött közösségnek az eltemetettel kapcsolatos, az időben mindig változó kulturális, szociális szokásainak ránk maradt

\footnotetext{
${ }^{6}$ Ennek megítéléséhez elegendő a Vereckei-szorost megtekinteni: azon csak egy lovascsapat tud átkelni! (A történeti kutatásról jó áttekintés: Müller-Wille-Schneider, 1993-1994.)
} 
töredékei. Ezzel szemben a történeti genetika előtt mindig az egyetlen és konkrét áll: maga a biológiai egyén, az ő egyéni, évezredekre visszanyúló családtörténetével, mégpedig a sokféle szempont alapján szerveződött közösségének kulturális, szociális megnyilvánulásai nélkül. Természetesen ideális az volna, ha teljes temetőket tudnánk genetikai vizsgálat alá venni; ez a költségek miatt legföljebb a kis lélekszámúak esetében remélhető; ezért a közelmúltig elégségesnek gondoltuk a 10. századi temetőket csak egy-egy, kiválasztott mintával vizsgálni. A kiterjedtebb elemzések azonban máris olyan történeti következtetések lehetöségére mutatnak, amelyek sok minden eddigit felülírhatnak; a genetika nem etnikumok, nem nyelvek ,azonosításával”, hanem a „temetőnek” mint régészeti és biológiai jelenségnek kutatásával tud perdöntően részt venni, az együvé temetkezés indítékait világíthatja meg. ${ }^{7}$

A mostanáig szoros családi közösségekének tartott honfoglalás kori temetö(részlete)k genetikai elemzései meghökkentő képet tárnak elénk. A kiskundorozsmai temetőben nyugvó három gyerek nem egymás testvérei és nem az ottani nők szülöttei (Csákyová et al., 2016). Egy esetben az anyát és gyermekét genetikailag bizonyítottan más-más temetőben, egymástól 100 km-re temették el! (CsőszMende, 2015, 373.) A hartai temető tizenhét sírja közül csak egy mtDNA egyezik meg másik csontvázéval, különös továbbá a férfiak és nők aránya is (2-15 fö, Langó et al., 2016). A szeged-öthalmi nyolc sír között még haplocsoport szinten sem volt egyezés, az ottani gyerekek sem testvérek, és egyikük sem a temetőben nyugvó egyetlen nő gyermeke (Csősz-Mende, 2015). Ugyanígy a szóládi langobárd temetőben csak a kisgyerekek születtek helyben, a felnőttek máshonnan jöttek (Alt et al., 2014). A Kárpát-medencei kora középkori temetőknek tehát az eddigi felfogástól eltérő struktúrája bontakozik ki, ami egy teljesen új társadalom- és gazdaságtörténeti szemléletet fog eredményezni.

Magyar(országi) perspektívák. Tegyük föl, hogy amiként a Human Genom Projectre sikerült összegyüjteni, nekünk az égből előteremne 900 milliárd forint - vajon egy ambiciózus „A magyarság genetikája” címü projekttel meg lehetne-e válaszolni a magyarság eredetével kapcsolatban sokunkat foglalkoztató kérdéseket? Hogy egy ilyennek hányféle szempontot kellene figyelembe vennie, arra a langobárdokkal kapcsolatban néhány éve folyó kutatások - egy modern temetöfeltárás és egy nemzetközi projekt - kínálnak tanulságokat.

Patrick Geary a kora középkori európai történelem kutatója (tájékoztatásul: Geary, 1988; 2014a), aki német, cseh, morva, magyar, olasz és észak-amerikai régészek és genetikusok szoros együttmüködésével kezdett bele egy valóban in-

${ }^{7}$ NB.: a Frank birodalomban feltárt temetőket prefeudális: nem családi, nem nemzetségi közösségek nyughelyeinek gondolják (lásd Mitterauer, 2003, 238.). Elgondolkodtató, hogy régészeti szempontból nézve a velük egyidejü avar kori temetők struktúrája, benépesülésének menete jobban hasonlít azokhoz, mint a kelet-európaiakhoz (lásd Szenthe, 2015, 296.). 
terdiszciplináris projektbe. Ehhez megbízható történeti eredmények és régészetileg jól kutatott területek kínálnak kiindulópontot. A nyugati germán eredetü langobárdok a feltételezett Elba-torkolatvidéki őshazájukból Thüringián, Morvaországon és Pannónián keresztül költöztek a Dunántúlra, végül 569 húsvéthétfőn Itáliába. A projekt célja nem pusztán genetikai minták gyüjtéséből, kiértékeléséből, valamint abból áll, hogy a genetikusok egy sor új adatot tesznek közzé, a közremüködő régészek pedig (sokadjára) megírják mindazt, amit a langobárd vándorlásról tudni lehet. A fentebb már érintett, részben módszertani kérdésekre keresnek válaszokat, amelyeknek megfogalmazása a történeti genetikában újszerü, míg a történész, régész számára kézenfekvő (Geary, 2014b; Vai et al., 2015; Geary-Veeremah, 2016): minek alapján szerveződtek a temetők, van-e rokonság - s ha igen, milyen fokú - a pannóniai temetők „langobárd” és a többi, a 6. század első felére keltezhető temetők halottai között?

A program kidolgozásakor arra hívtam föl Patrick Geary figyelmét, hogy nem elég csak a langobárd kori temetőket vizsgálni, de a Kárpát-medenceiek esetében szükség lenne még a velük egy időben élt és szomszédos keleti germán gepidákét is. (Ök a Visztula torkolatvidékétől Mazurián át vezető vándorlás után telepedtek meg a Magyar Alföldön.) Van-e, és mi lehet egyezö és mi eltérő e két nép temetőinek genetikai képében? Van-e bennük közös, „germán” elem? A dunántúli „langobárd” temetőkben van-e nyoma a helyben talált lakosságnak? Ki lehet-e mutatni olyan „langobárdokat” 569 utánról, akik itt maradtak? Ez a kutatás most folyik, és nemcsak eredmények, de általános(itható) tanulságok is várhatók tőle.

Hasonló programot elindítani az ősmagyar etnogenezisről nemcsak anyagi okból, de az alapot szolgáltató tudományágak helyzete miatt is összehasonlíthatatlanul nehezebb lenne. A magyar őshazákról, vándorlásokról sokféle elmélet van, de azokat a történészek és nyelvészek másfél évszázada ugyanabból a néhány puzzle-darabból állítják össze. Az értékelésnek az a súlyos módszertani terhe, hogy nem is sejtjük: egyáltalán hány „,puzzle-készletből” valók a kezünkben levő darabok? Az(ok az) „,eredeti kép(ek)” hány darabból állhatott(állhattak)? Mennyire illeszthetők össze egymással az írásos forrásadatok? Azok mindegyike ui. csak egy adott történeti pillanatban volt érvényes, ami a különösen forgandó sztyeppei történelem esetében nagy óvatosságra int. A történeti és a nyelvészeti adatok száma lényegesen már nem gyarapodik, míg a régészetieké az elmúlt fél évszázad alatt nagyon (azok interpretációi is). Mármost, egy újonnan fölfedezett régészeti „puzzle-elem” lehetővé/szükségessé teszi-e új képek alkotását? Mennyire alkalmasak a régészeti leletek eseménytörténeti folyamatok rekonstruálására? A történeti genetika megfigyelései éppen az ilyen problémák remélt, lassan várható megvilágítása révén juthatnak majd kiemelt szerephez.

A magyar őstörténet kutatását a langobárdokéval összehasonlítva: jelenleg az ősmagyar vándorlásoknak sem az állomásait, sem azok időbeliségét még csak 
megközelítőleg sem ismerjük hasonlóan jól. Az egyes elméletek közti véleménykülönbségek ezer kilométerekben is mérhetők, az eddig számításba vett „őshazák” külön-külön is Kárpát-medence nagyságúak, amelyek régészeti kutatottsága messze nem mérhető az utóbbiéhoz - márpedig mi, közép-európai régészek jól látjuk, hogy errefelé mekkora etnikai-kulturális különbségek voltak jóval kisebb régiókon belül is. A friss ásatások, a raktárakban tett fölfedezések mindennap új leleteket kínálnak értékelésre, ami különösen az internet világa és a tudományos élet velejárói (konferenciák, idézettség) miatt roppant csábító, de figyelmeztet is: a holnapi leletek fényében a mai interpretációk ugyanúgy csak egy kutatástörténeti fejezetbe kerülhetnek; ebben ígér a genomika új korszakot. Valóban új és a szó szoros értelmében vett elmélettel célszerübb csak egy-egy kutatástörténeti korszak vége felé előállni, amint az most zajlik a 6-7. századi meroving és a 9-10. századi viking régészetben, márpedig azok kutatottsága nem hasonlítható a kelet-európaiakéhoz. A genetikai mintavétel szempontjait ne „szenzációs” leletek, frissen született interpretációk irányítsák, hanem kezdjünk inkább a házunk táján. A Kárpát-medence több régióját és több korszakát felölelő kutatás nemcsak megbízható kiindulópontot kínálhatna a kelet-európai és ázsiai mintákkal való jövőbeni összehasonlításhoz, de egész Közép-Európa történeti genetikai képét segítené fölvázolni. Addig pedig türelmet kívánok mindenkinek: kutatóknak, társadalomnak egyaránt.

A fentiekben a jelenlegi történeti genetikai kutatás több bizonytalanságáról esett szó - valójában néhányan a régészeti korokból való temetők népessége eredetkérdése megítélésében mentek túl a módszertanilag megengedhetőnél. Világszerte egyértelműnek számít: határozott különbséget kell tenni a 'nép', a 'nyelv', a 'populáció' fogalmak és a régészeti kultúra között (lásd legutóbb Róna-Tas, 2017). Megismétlem: ez az új diszciplína - a leküzdendő gyerekbetegségeivel is - az emberi és állatcsontok, valamint a növénymaradványok vizsgálata és a temetők mibenlétének értelmezésében nyújtott segítsége révén a múlt feltárásában rendkívül értékes forráscsoportot jelent; perspektívái reménykeltőek.

A Walter Pohl vezette, folyamatban levö ERC Advanced Grant Social Cohesion, Identity \& Religion in Europe 400-1200 projekt „Genetic History and Medieval Ethnicity” című részének tervezetében ez áll: „Az 1980-as évek óta nagy remények támadtak, hogy a genetika meg tudja mondani »kik vagyunk«, »honnan jöttünk«. E remények többnyire a történeti evidenciák figyelmen kívül hagyásával és a genetikai (és nyelvészeti) jegyeknek történeti népekhez való átgondolatlan kapcsolásával párosultak. 1945 után a történeti kutatás a népek kialakulásának kutatásában azonban elmozdult az etnicitás biológiai megközelítésétől, és azt kulturális és történeti megvilágításba helyezte." 


\section{IRODALOM}

Alt, K. W. - Knipper, C. - Peters, D. et al. (2014): Lombards on the Move - An Integrative Study of the Migration Period Cemetery at Szólád, Hungary. PLOS ONE, 9(11): e110793 DOI:10.1371/ journal.pone.0110793, http://journals.plos.org/plosone/article?id=10.1371/journal.pone.0110793

Bálint Cs. (2008): A történeti genetika és az eredetkérdés(ek). (A közös kutatás szükségessége és lehetőségei.) Magyar Tudomány, 169, 10, 1170-1187. http://www.matud.iif.hu/08okt/02.html

Bánffy, E.- Brandt, G. - Alt, K. W. (2012): 'Early Neolithic' Graves of the Carpathian Basin Are in Fact 6000 Years Younger - Appeal for Real Interdisciplinarity between Archaeology and Ancient DNA Research. Journal of Human Genetics, 57, 467-469. DOI: 10.1038/jhg.2012.36, https://www.nature.com/articles/jhg201236

Bateman, R. M. - Goddard, I. - O'Grady, R. et al. (1990): The Feasibility of Reconciling Human Phylology and the History of Language. Current Anthropology, 31, 1, 1-24.

Berta Á. (2004): Szavaimat jól halljátok... A türk és ujgur rovásírásos emlékek kritikai kiadása. Szeged: JATE Press

Brather, S. (2004): Ethnische Interpretationen in der frühgeschichtlichen Archäologie. Geschichte, Grundlagen und Alternativen. Berlin-New York: de Gruyter

Cavalli-Sforza, L. L. (2001): Genes, Peoples and Languages. University of California Press

Cavalli-Sforza, L. L. (2002): Genetikai átjáró - különbözöségünk története. (ford. Tábori Z.) (HVG Könyvek) Budapest: HVG Kiadó

Cavalli-Sforza, L. L. - Menozzi, P. - Piazza, A. (1994): The History and Geography of Human Genes. Princeton: Princeton University Press

Csákyová, V. - Szécsényi-Nagy, A. - Csősz A. et al. (2016): Maternal Genetic Composition of a Medieval Population from a Hungarian-Slavic Contact Zone in Central Europe. PLOS ONE, 11(3): e0151206 DOI:10.1371/journal.pone.0151206, http://journals.plos.org/plosone/article?id=10.1371/journal.pone. 0151206

Csősz A. - Mende B. G. (2015): Archeogenetikai vizsgálatok Szeged-Kiskundorozsma-Hosszúhát és Szeged-Öthalom lelőhelyek 10. századi népességén. In: Türk A. - Lőrinczy G. - Marcsik A. (szerk.): Régészeti és természettudományi adatok a Maros-torkolat nyugati oldalának 10. századi történetéhez. Budapest: PPKE-MTA BTK, 371-375.

Geary, P. (1988): Before France and Germany: The Creation and Transformation of the Merovingian World. New York: Oxford University Press

Geary, P. (2014a): A nemzetek mitosza. Európa népeinek születése a középkorban. (ford. Duró G.) (CIRCUS MAXIMUS sorozat) Budapest: Atlantisz Könyvkiadó

Geary, P. (2014b): Rethinking Barbarian Invasions through Genomic History. Hungarian Archaeology Online E-Journal, Autumn, 1-8. http://www.hungarianarchaeology.hu/wp-content/uploads/2014/11/eng_geary_14O.pdf

Geary, P. J. - Veeremah, K. (2016): Mapping European Population Movement through Genomic Research. Medieval Worlds, 4, 65-78. DOI 10.1553/medievalworlds_no4_2016s65, http://www. medievalworlds.net/0xclaa500e_0x00348d15.pdf

Gillett, A. (ed.) (2002): On Barbarian Identity. Critical Approaches to Ethnicity in the Early Middle Ages. Turnhout: Brepols Publishers

Grenoble, L. A. (2011): Language Ecology and Endangerment. In: Austin, P. K. - Sallabank, J. (eds.): Handbook of Endangered Languages. Cambridge: Cambridge University Press, 27-44.

Guba Zs. - Hadadi É. - Major É. et al. (2011): HVS-I Polymorphism Screening of Ancient Human Mitochondrial DNA Provides Evidence for N9a Discontinuity and East Asian Haplogroups in the Neolithic Hungary. Journal of Human Genetics, 56, 784-796. DOI:10.1038/jhg.2011.103, https://www.nature.com/articles/jhg2011103 
Honti L. (2004): Mítoszok a magyar nyelv eredete körül. Nyelvtudományi Közlemények, 101, 137151. http://real-j.mtak.hu/2773/1/NyelvtudomanyiKozlemenyek_101.pdf

Keyser-Tracqui, C. - Crubézy, E. - Pamzsav, H. et al. (2006): Population origins in Mongolia: genetic structure analysis of ancient and modern DNA. American Journal of Physical Anthropology, Oct. 131, 2, 272-281. DOI: 10.1002/ajpa.20429, https://goo.gl/j7jj8y

Kowaleski, M. (2013): Gendering Demographic Change in the Middle Ages. In: Benett, J. M. Karras, R. M. (eds.): The Oxford Handbook of Women and Gender in Medieval Europe. Oxford: Oxford University Press, 223-247. https://goo.gl/Q8Japw

Langó P. - Kustár R. - Köhler K. - Csősz A. (2016): A Study of the Tenth-century Cemetery at Harta-Freifelt. Antaeus, 34, 389-416. https://goo.gl/uFkviD

Mitterauer, M. (2003): Mittelalter. In: Gestrich, A. - Krause, J.-U. -Mitterauer, M. (eds.): Geschichte der Familie. Europäische Kulturgeschichte. 1. Stuttgart: Alfred Kröner Verlag, 160363.

Müller-Wille, M. - Schneider, R. (eds.) (1993-1994): Ausgewählte Probleme europäischer Landnahmen des Früh- und Hochmittelalters. Methodologische Grundlagendiskussion im Grenzbereich zwischen Archäologie und Geschichte. I/II. (Vorträge und Forschungen, Band 41) Sigmaringen: Jan Thorbecke Verlag

Pamjav, H. - Fehér T. - Németh E. et al. (2016): Genetika és östörténet. A magyarok és más eurázsiai népek múltja a genetikai adatok fényében. Budapest: Cédrus Mủvészeti AlapítványNapkút Kiadó

Priskin K. (2010): A Kárpát-medence honfoglalás kori lóállományának archaeogenetikai elemzése. Szeged, PhD-disszertáció, http://doktori.bibl.u-szeged.hu/911/

Róna-Tas A. (2017): A tudományok határai. Magyar Tudomány, 178, 10, 1298-1302. DOI: 10.1556/2065.178.2017.10.13, https://mersz.hu/?xmlazonosito=matud_19\#matud_19

Simon Zs. (2005): Iam proximus ardet Ucalegon. Magyar Tudomány, 166, 9, 1152-1157. http:// www.matud.iif.hu/05sze/11.html

Szenthe G. (2015): Über die Aussagekraft der Hinterlassenschaft einer Heidenelite: Spätawarenzeitliche Funde auf dem Prüfstand. In: Heinrich-Tamaska, O. - Herold, H. - Straub, P. - Vida, T. (eds.): „Castellum, civitas, urbs”. Zentren und Eliten in frühmittelalterlichen Ostmitteleuropa. Budapest-Leipzig-Keszthely-Rahden/Westf., 293-312. https://www.academia. edu/11532752/\%C3\%9Cber_die_Aussagekraft_der_Hinterlassenschaft_einer_Heidenelite_ Sp\%C3\%A4tawarenzeitliche_Funde_auf_dem_Pr $\% \bar{C} 3 \%$ BCfstand

Vai, S. - Ghirotto, S. - Pilli, E. et al. (2015): Genealogical Relationships between Early Medieval and Modern Inhabitants of Piedmont. PLOS ONE, 10(1): e0116801. DOI:10.1371/journal/ pone.0115601, http://journals.plos.org/plosone/article?id=10.1371/journal.pone.0116801

URL1: https://en.wikipedia.org/wiki/Etruscan_origins 